\title{
Jeremy Safran: a hero's journey
}

\author{
Adam Otto Horvath \\ Faculty of Education, Simon Fraser University, Vancouver, Canada
}

\begin{abstract}
In this essay I explore Jeremy Safran's intellectual career as a hero's journey or monomyth within the specific context of psychotherapy research. I argue that he fits such model in the sense that his work - though deeply informed by theories - was singularly focused and driven by his own sense of his role and mission within the profession. Rather than attempting to review in detail the entire scope or specific parts of his research contributions, I look at his scholarship as a kind of quest, a pursuit that was trans-theoretical but unified by foundational questions about the unique nature of the relationship between therapist and patient.
\end{abstract}

Key words: In memoriam; Jeremy Safran; hero.

Gently they go, the beautiful, the tender, the kind; Quietly they go, the intelligent, the witty, the brave. I know. But I do not approve. And I am not resigned.

\section{Dirge without music: Edna St. Vincent Millay}

\section{On remembering}

When asked to contribute to this special section I felt honored, and at the same time discomforted. Jeremy was a friend first before a colleague, and to write about his work, to distance myself from my own sense of loss, to address his accomplishments objectively, was challenging, and likely only partially achieved. In this short essay it is not my intent to review the full ark and span of his

Correspondence: Adam Otto Horvath, Faculty of Education, Simon Fraser University, Vancouver, Canada.

E-mail: horvath@sfu.ca

Citation: Horvath, A.O. (2019). Jeremy Safran: a hero's journey. Research in Psychotherapy: Psychopathology, Process and Outcome, 22(1), 3-6. doi: 10.4081/ripppo.2019.380

Conflict of interest: the author declares no potential conflict of interest.

Funding: Simon Fraser University R.R. Fund, Faculty of Education.

Received for publication: 2 February 2019.

Accepted for publication: 5 March 2019.

This work is licensed under a Creative Commons Attribution NonCommercial 4.0 License (CC BY-NC 4.0).

CCopyright A.O. Horvath, 2019

Licensee PAGEPress, Italy

Research in Psychotherapy:

Psychopathology, Process and Outcome 2019; 22:3-6

doi:10.4081/ripppo.2019.380 professional contributions - an important task but not mine - nor will I try to condense or sum up a life's work, a task which I think would be contrary to his contextualized way of looking at such things. I set myself a more modest task of trying to put in context my friend and colleague's intellectual journey.

My reference in the title to a hero's journey was not intended as a qualitative adjective to lionize his contributions but rather to characterize his intellectual legacy. I use the term a hero's journey in reference to the concept of monomyth in the sense that Rank, Richter and Liebermann (2004), Jung and Hull (1990) and Joseph Campbell (2000) used the term to offer a perspective on what he has left us in the context of an intellectual life in-time his call to adventure and his pursuit into the unknown.

\section{The beginning (as I knew it)}

Jeremy and I got our doctorate at the same university and overlapped in our studies for three years. Like many universities at the time, (we are speaking of the late ' 70 's) there were two separate departments granting doctorates in psychology. On one side was the Department of Clinical Psychology (DCP) staffed by reputable behaviorists like R. Dobson and R.J. Rachman. The DCP was housed in modern facilities, complete with one-way mirrored labs, video cameras etc., in a bespoke new building. On the other side, across the "L" parking lot was the Counselling Psychology department housed in Quonset shacks left over from a WW II army training camp. In this department you could find the likes of Les Greenberg, people interested in the ideas of Rogers, Fritz Perls and the humanists.

The two sources graduate degrees in psychology ran on parallel but separate tracks. Even the research design and statistics courses, though thought mostly by the same professors, had different course numbers in each depart- 
ment. A mixture of theoretical and ideological fealty typical at the time - kept the two groups of faculty and graduate students apart and slightly paranoid of each other. The presence of at least three incompatible comprehensive theories of psychotherapy, competing for primacy in use at that time, was interpreted to mean that there could be but one correct broad conceptual framework, and the others relied on imperfect misuse of techniques better understood/explained by the right theory. Or worse: the nefarious placebo effect. Researchers expended considerable energy and resources to conclusively prove the superiority of their favored orientation. One can get a good sense of the partisan atmosphere within the field at this time by reading Eysenck's (1952) famous article disparaging psychodynamic treatment and promoting behavioral approaches, and the strong response to his claims e.g. (Strupp, 1963).

It was in this Gemeinschaft that Jeremy Safran floated, quietly and seemingly without effort into our circle on the non-behavioral side of the campus. He became a regular feature of our informal gatherings (students and faculty) where - as often the case in graduate programs - all the interesting emerging ideas were discussed, and most productive learning experiences took place. Importantly, he never rejected the clinical psychology group, CBT theory, or came over to our side formally or informally. He simply questioned, participated, and made friends. Evidently the partisan theoretical divisions, the reality for most of the graduate students, did not even occur to him. I cannot recall him critiquing the status quo of competition among theories explicitly. Rather it was his ability, even as a graduate student, not to be owned or pay fealty to any intellectual club or collective. He had passionate loyalty to questions that he thought were important, and he was interested in listening to all the voices that shared his interests.

His thesis was about the way cognitive processes mediate expectations and the interpretation of interpersonal behavior (Safran, 1983). But in our conversations he seldom mentioned this specific topic, he was interested on how therapy worked, how people changed. Differences in theories and the varieties of clinical modus operandi was the reason to ask, not a source of explanation.

According to Campbell, the hero's journey begins with a call. In the summer of 1980, I was working for a branch of the provincial ministry serving people with substance abuse issues. Due to some unusual circumstances - clearly nothing to do with my abilities - I was rapidly promoted to head psychologist. The task was way over my head and urgently needed somebody competent to help me deal with the situation. Jeremy needed a summer job. I hired him and was rewarded with long rides all over the province in his company in my rusty Volkswagen beetle. It was during one of these rides he mentioned briefly tragedies in his personal life. He was a very private person, when he spoke, he was direct; an exchange between friends, he did not psychologize the impact of these events. But looking back, if I was to look for a spark the ignited the quest, I would start there.

\section{The journey}

Jeremy Safran's long list of professional publications read like road map: On one hand he spoken to a remarkably wide range of audience. In historical sequence, he starts off addressing the CBT and behavioral community (e.g., Alden, Safran, \& Weideman, 1978; Safran, 1983; Safran \& Greenberg, 1982a; Safran, Vallis, Segal, \& Shaw, 1986). Somewhat overlapping with these pieces he is beginning to address a wider more inclusive audience (e.g., Greenberg \& Safran, 1989; Safran, 1992; Safran, Greenberg, \& Rice, 1988) and broadens, progressively, the scope of topics he is looking at. He explores issues from the perspectives of interpersonal theory and the starts to comment on the links between these concepts viewed from different theoretical perspectives (i.e., psychotherapy integration) but without discontinuing the dialogue with the CBT audience (Safran \& McMain, 1992; Safran, Segal, Vallis, Shaw, \& Samstag, 1993). Without neglecting these audiences he engaged the psychodynamic community starting in '99 (Safran, 1999, 2001), and adds the dimension of Buddhism and philosophy of psychotherapy (Safran, 2003).

But, on the other hand, while he appears to turn to different audiences over these three decades and move his vision across the theoretical spectrum, there is a remarkable internal consistency and cohesiveness among the issues he was working on and interested in. The uniqueness of his journey and contribution is the freedom, indeed enthusiasm, to explore the phenomenon of psychotherapy through different theoretical lenses in depth, and with full use of the intellectual insights and resources afforded by these different theories, without apparent loyalty or commitment to the theory as such. He is interested in issues, such as epistemological aspects of the therapy process how do clients change their ideas and what influences their appraisal (Safran, 1984); the interaction of affect and cognition in therapy (Safran \& Greenberg, 1982b) and, most importantly, the concept of therapy as interactive encounter between two humans, a two person event in the fullest sense that involves dynamic and mutual influence at the conscious and unconscious levels.

What is unique in his approach is that unlike most of his contemporaries he was able to consistently priorize and focus on the issues and treated theoretical lenses as tools to address, from a variety of perspectives, what he considered to be the important questions in understanding how therapy works.

On a single occasion that we talked about his relationship to theories - I awkwardly teased him about first encountering him as a $C B T$ person and now having to squeeze beside him on his analytic couch (we were sharing accommodations at an APA conference). He smiled, turned quite 
serious, and said "Well...you know...they [each] have some interesting things to say about stuff I've been thinking about". While many of us are honestly convinced that much of what works in therapy are not exclusive to the methods of any one theory, and common factors are at the heart of understanding the nature of psychotherapy, at the core, even those who are committed to psychotherapy integration, each come from a place. Even those who identify as eclectic, at the core of their personal theory, have an affinity - if not an orthodox fealty - to a theoretical home base. Most psychotherapist relay to some extent on a cohesive comprehensive theory to help them rise above the whirlpool of confused and confusing world of the patient, and think about a new road forward, a pathway to change beyond those already exhausted by the client. Likewise, researchers need a logically coherent framework to formulate questions, to identify issues that matter. It is a very difficult task to invent the wheel anew to build a cohesive structure to guide the inquiry from the ground up; it is much more efficient and convenient to make use of a well-articulated model, perhaps with some modifications, and with an open mind to alternative concepts. Thus, most of us end up habitually aligned with one of the mayor theoretical models. What, for me, is interesting and heroic about Jeremy's legacy is both his openness to find truths trough different theoretical prisms and his ability to maintain a skeptical outsider position throughout his intellectual and clinical journey. He was particularly impressed and interested in the contributions of other outsiders like Ferenczy, Rank and some of the Zen Buddhist masters. He shared with them the rare quality of intellectual independence, the strength of believing in his own questions, and the confidence of sometimes standing apart.

His intellectual independence was of a very particular kind. Unlike independent thinkers who are reactive to the mainstream thinking and make the point of departure identifying what is missed missing or wrong-footed in the common wisdom, Jeremy had - at least in the conversations I was a part of - a very distinctive way of engaging with a topic. He would typically join in the conversation by enthusiastically amplifying the previous comment "Yes! Yes! Exactly...(repeat)... and you know....." after the you know came inevitably some comment from a new place, a new source, a different angle. It was not instead it was in addition making the conversation bigger more interesting more inclusive. But his take on the issue was seldom just additive. $\mathrm{He}-$ both in verbal discussion and in his published work - started from a different take on what the core, of the issues were. Two examples of his approach are his pieces The unbearable lightness of being: Authenticity and the search for the real and Psychotherapy integration: A postmodern critique (Safran, 2017; Safran \& Messer, 2015). In both cases he identifies issues at the center of the prior discourse that others have missed or overlooked without ever explicitly formulating his case as a critique but, by putting the matter into a different, more compre- hensive context, he challenges profoundly the more traditional views. In the first case, the notion of authenticity is explored historically as a social phenomenon. He brings attention to the neglected ethical dimension of being real, the interactive nature of one's sense of identity, and the moral implications of the value placed on becoming genuine and authentic. The re-considering of these neglected dimensions of the values attributed to authenticity challenge and elevate the discourse on the subject, not only within the psychoanalytic community (the paper was published in Psychoanalytic Psychology - Safran, 2017) but equally relevant to therapist of all orientation.

The chapter - originally published as an article - Psychotherapy integration: A postmodern critique (Safran \& Messer, 2015) likewise starts with re-casting the inquiry about the aims and limits of psychotherapy integration into a larger socio-historical context. Like in the previous example, the re-framing of the question, the re-formulating of the context (from the technical/theoretical to the historical social) opens up the discussion in a new dimension. They do not premise the paper on marshalling a critique: what has been over looked? But point out that the core issue lies in understanding the challenge of integrating different theoretical visions as a part of a larger intellectual current and bring the understandings and critique of intellectual pluralism and post-modern philosophy to provide a more inclusive, richer, context in which the limits of integrating diverse theories can be appreciated.

Jeremy has made contributions to an amazing variety of subjects, especially considering his tragically short career. Many of us know of him for his contributions to the alliance research and especially his work on intersubjectivity. Rather than exploring these specific and very important fields of contributions I chose to focus on his particular style of intellect, the journey of an independent thinker, a quality that I think we should particularly treasure.

Naturally, this short essay is a very incomplete and biased glance backwards to a very complete and accomplished friend and colleague. Perhaps a more just and complete summary of Jeremy Safran life and contributions is to be found in the sum of memorials and memories of all who remember him fondly, including this special volume. His life was tragically shortened, and we are all the poorer for it.

\section{References}

Alden, L., Safran, J., \& Weideman, R. (1978). A comparison of cognitive and skills training strategies in the treatment of unassertive clients. Behavior Therapy, 9(5), 843-846. doi: 10.1016/S0005-7894(78)80015-X

Campbell, J. (1992). The Hero's Adventure: Power of Myth 1Audio Recording (HighBridge Audio) ISBN 0942110935 (ISBN13: 9780942110937).

Eysenck, H. J. (1952). The effects of psychotherapy: An evaluation. Journal of Consulting and Clinical Psychology, 16, 319-324. 
Greenberg, L. S., \& Safran, J. D. (1989). Emotion in psychotherapy. American Psychologist, 44(1), 19-29. doi: 10.1037/ 0003-066X.44.1.19

Jung, C. G., \& Hull, R. F. C. (1990). The basic writings of C. G. Jung. Princeton, NJ: Princeton University Press.

Rank, O., Richter, G. C., \& Lieberman, E. J. (2004). The myth of the birth of the hero: A psychological exploration of myth, Exp \& updated ed. Baltimore, MD: Johns Hopkins University Press.

Safran, J. D. (1983). Cognitive processes mediating the effect of expectations on the perception of interpersonal behavior. (43), ProQuest Information \& Learning. Available from: EBSCOhost psyh database.

Safran, J. D. (1984). Assessing the cognitive-interpersonal cycle. Cognitive Therapy and Research, 4, 333-348.

Safran, J. D. (1992). Extending the pantheoretical applications of interpersonal inventories. Journal of Psychotherapy Integration, 2(2), 101-105. doi:10.1037/h0101247

Safran, J. D. (1999). Faith, despair, will and the paradox of acceptance. Contemporary Psychoanalysis, 35(1), 5-23. doi: 10.1080/00107530.1999.10746378

Safran, J. D. (2001). When worlds collide: Psychoanalysis and the empirically supported treatment movement. Psychoanalytic Dialogues, 11(4), 659-681. doi: 10.1080/ 10481881109348635

Safran, J., D. (Ed.). (2003). Psychoanalysis and Buddhism: An unfolding Dialogue. Boston: Wisdom Publications.

Safran, J. D. (2017). The unbearable lightness of being: Authenticity and the search for the real. Psychoanalytic Psychology, 34(1), 69-77. doi: 10.1037/pap0000093

Safran, J. D., \& Greenberg, L. S. (1982a). Cognitive appraisal and reappraisal: Implications for clinical practice. Cognitive Therapy and Research, 6(3), 251-258. doi:10.1007/ BF01173574

Safran, J. D., \& Greenberg, L. S. (1982b). Eliciting 'hot cognitions' in cognitive behaviour therapy: Rationale and procedural guidelines. Canadian Psychology/Psychologie canadienne, 23(2), 83-87. doi: 10.1037/h0081247

Safran, J. D., Greenberg, L. S., \& Rice, L. N. (1988). Integrating psychotherapy research and practice: Modeling the change process. Psychotherapy: Theory, Research, Practice, Training, 25(1), 1-17. doi: 10.1037/h0085305

Safran, J. D., \& McMain, S. (1992). A cognitive interpersonal approach to the treatment of personality disorders. Journal of Cognitive Psychotherapy, 6(1), 59-68.

Safran, J. D., \& Messer, S. B. (2015). Psychotherapy integration: A postmodern critique. In J. Bresler, K. Starr, J. Bresler, \& K. Starr (Eds.), Relational psychoanalysis and psychotherapy integration: An evolving synergy. (pp. 19-38). New York, NY, US: Routledge/Taylor \& Francis Group.

Safran, J. D., Segal, Z. V., Vallis, T. M., Shaw, B. F., \& Samstag, L. W. (1993). Assessing patient suitability for short-term cognitive therapy with an interpersonal focus. Cognitive Therapy and Research, 17(1), 23-38. doi: 10.1007/ BF01172738

Safran, J. D., Vallis, T. M., Segal, Z. V., \& Shaw, B. F. (1986). Assessment of core cognitive processes in cognitive therapy. Cognitive Therapy and Research, 10(5), 509-526. doi: 10.1007/BF01177815

Strupp, H. H. (1963). The outcome problem in psychotherapy revisited. Psychotherapy: Theory, Research, and Practice, 1(1), 1-13. 